\title{
An Empirical Study on Social Education of Chinese Museums
}

\author{
Fen Liu ${ }^{1}$, Wenbin $\mathrm{Liu}^{2 *}$ and Jin Yang ${ }^{3}$ \\ ${ }^{1 / 3}$ Wuhan Business and Technology University, Wuhan 430065, China \\ ${ }^{2}$ Deartment of Public Course, Wuhan Technology and Business University, Wuhan 430065, China
}

( ${ }^{\star}$ Corresponding Author: Wenbin Liu, email:812926096@qq.com)

Keywords: Hubei provincial museum; Social education; Activities; Official website

\begin{abstract}
Based on the data on the official website of Hubei Provincial Museum from 2011-2017, this study summarized the patterns and contents of the activities Hubei Provincial Museum had taken in realizing its educational function, and put forwards some countermeasures to promote the function of education of museums.
\end{abstract}

\section{Introduction}

In January 2018, the State Administration of Cultural Heritage of China published "the National Museum Directory of 2016", releasing 4826 museums in this directory. As the common wealth of all mankind, museums are important educational institutions shared by all human beings. While in China, social education practice and research on museums have just started. More researches are needed to make full use of the abundant educational resource of Chinese museums and achieve their functions as educational institutes.

According to former researchers, there are some major problems that need to be solved: 1) Conceptual problem: Some museum staff still take the role of museums as collecting, protecting and researching on the cultural relics and responsible only for national cultural heritage, government and academics (Shan Jixiang, 2011); 2) waste of museum resources: there are serious problems in the waste of collections, research resources and educational resources in Chinese museums (Li Mei, 2008); low utilization rate of museums in Chinese schools, a very big gap between schools and museums (Anderson, 2017); 3) The lack of subdivision of educational objects: Most museums do not separate adult education from child education (Pan Yao, 2014); 4) The backwardness of educational technology means: Museum educators have rich museum knowledge but lack corresponding teaching skills (Zheng Xudong, 2015); museum education stays at the level of preaching and teaching (Pan Yao, 2014); the discipline construction is still immature and the research is inadequate(Zhang Guochao, 2012); educational content is fragmented and lacks systematic arrangement (Yu Hua, 2017); 4) There is a lack of effective integration between informal education in museums and formal education in schools (Anderson, 2017).

In summary, researches at home and abroad lays the foundation for the development of museums and the realization of their education, one of the three key functions of museums. While most Chinese museums lack of education quality testing, and subjectivity, blindness and randomness have become major factors influencing the quality of museum education (China Society of Museum Science and Technology Committee, 2007).

\section{Research Methodology}

This article aims at investigating the status quo of social education of Chinese museums by taking Hubei Provincial Museum as the research object. We collect the data based on the texts and pictures from the official website issued by Hubei Provincial Museum January 2011 to December 2017, and analyze the form, object, frequency, characteristics and contents of educational activities taken by the educational department of Hubei Provincial Museum. Miller \& Crabtree's (1992) research model was used in research design to define research questions, form hypotheses, collect data, analyze data, draw conclusions, and make recommendations. 
This study proposes the following problem assumptions:

What kind of social educational activities have museums taken?

Who have been targeted as the teaching objects?

Where have been taken as the best place to carry out social education?

\section{Research Findings}

Assumption 1: What kind of social educational activities have museums taken? Are they acceptable?

This study categorized the education activities organized by Hubei Provincial Museum over the past seven years, including exhibition activities, volunteer activities, teaching programs, visitor experiences, lectures activities, and other activities for each year. The contents and characteristics are shown in Figure 1:

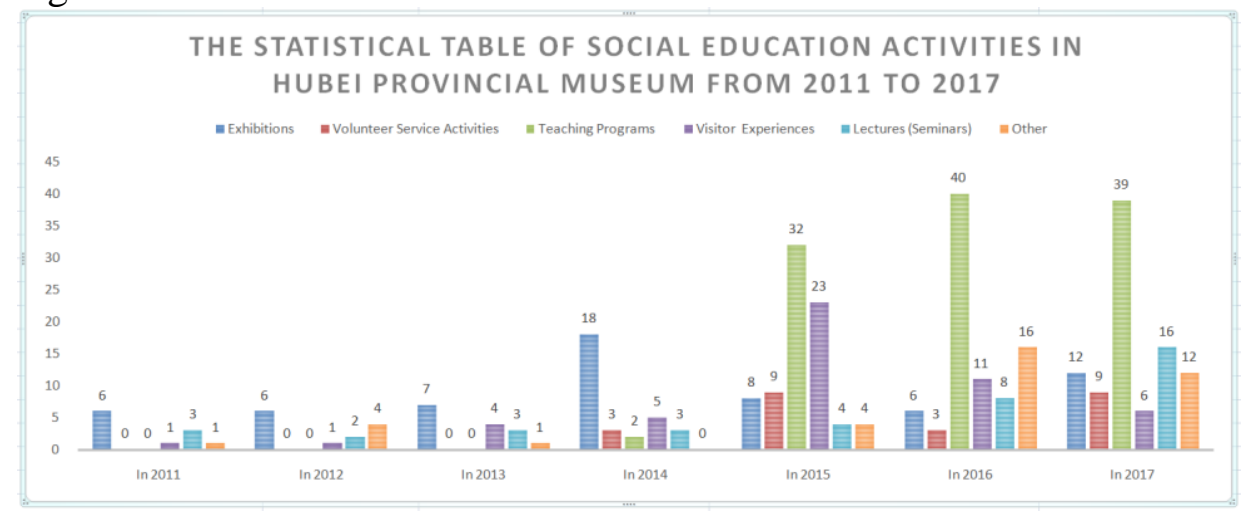

Figure 1. The Statistical Table of Social Education Activities in Hubei Provincial Museum from 2011 to 2017

From Figure1, we can clearly conclude that all the education activities organized by Hubei Provincial Museum over the past seven years were increasing annually. Year 2015 is the key point for the change of the educational form for the museum. Teaching programs and visitor experiences were increased severely. The drastic changes in the organizational activities should be greatly influenced by the "Outline for Medium and Long-Term Development of Museum Projects (2011-2020)" promulgated by Ministry of Education of China, which reflected the direct impact of governmental policies and regulations on the social education of museums.

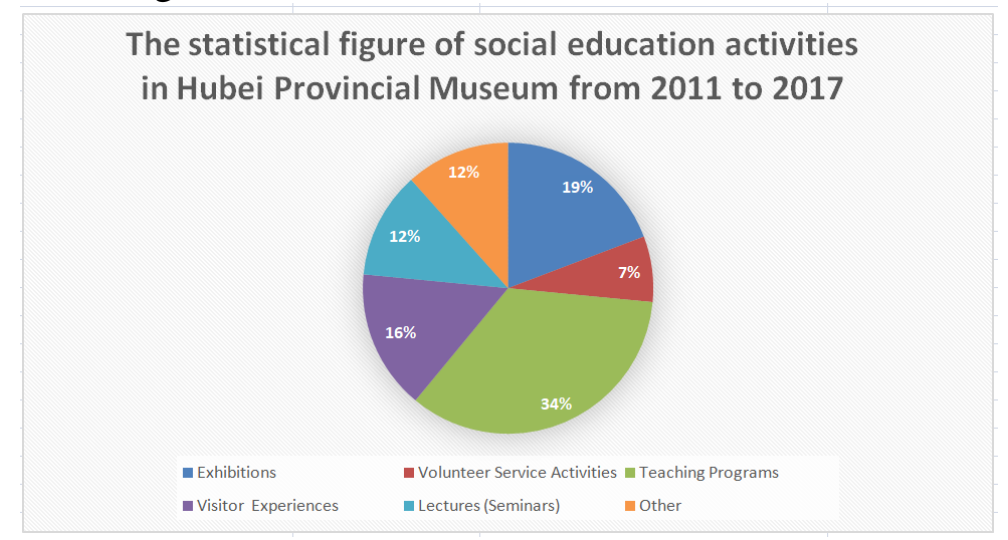

Figure 2. The Statistical Figure of Social Education Activities in Hubei Provincial Museum from 2011-2017

From Figure 2, it can be seen that during the 7 years teaching programs have accounted for $34 \%$. Unfortunately, in the current research on the three major functions of museums, there is no empirical research to explore what proportions of exhibitions, education, and visitor's interactive activities should be a relatively scientific and rational allocation. 
But what kind of teaching program is most favored by visitors? How do education department arrange their teaching program? These questions are still open to researchers. More visitors' feedbacks are needed to improve the social education of museums.

Assumption2: Who have been targeted as the teaching objects? Who should be targeted as the teaching objects?

In order to attract audiences and play the role of social education, Hubei Provincial Museum organized a series of teaching programs to enter the campus. The specific campus teaching programs are shown in Figure3:

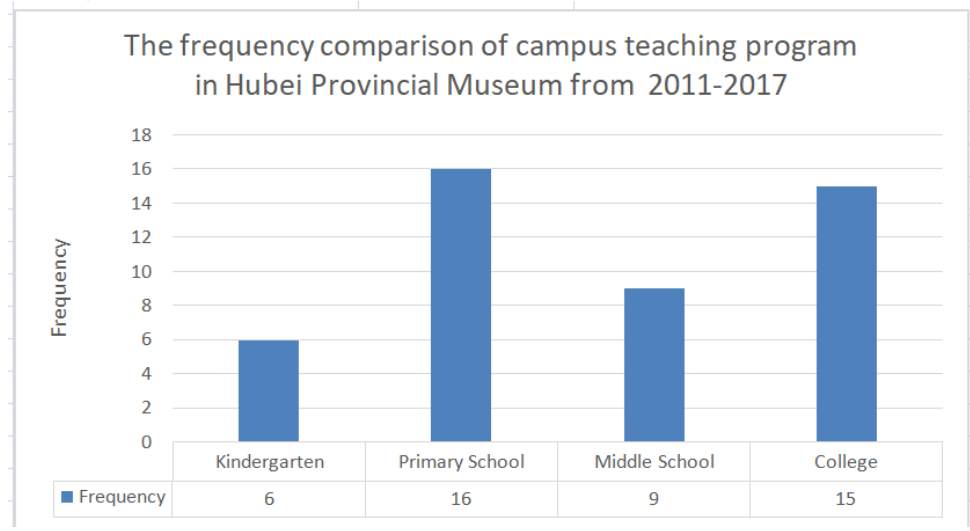

Figure 3. The Frequency Comparison of Campus Teaching Program in Hubei Provincial Museum from 2011 to 2017

In Figure 3, we can see that the teaching staff of Hubei Provincial Museum chose more teaching programs in primary schools and colleges, 16 and 15 times during these 7 years respectively, while less teaching programs in kindergartens and middle schools.

Why have the primary school students and college students been targeted as the teaching objects by the teaching staff of Hubei Provincial Museum? Have researchers studied who need the social education of the museums most? Have museum education department made a scientific and systematic teaching program according to different teaching objects? There should be more investigation on these problems to improve the social education of museums.

Assumption 3: Where have been taken as the best place to carry out social education?

According to the experience in American and other museum education, museums are the best site for carrying out social education. In this research, Hubei Provincial Museum carried out most their social education in the museum, which accounts 52\% from 2016 to 2017, which proved that the museum is still a most favored site for social education.

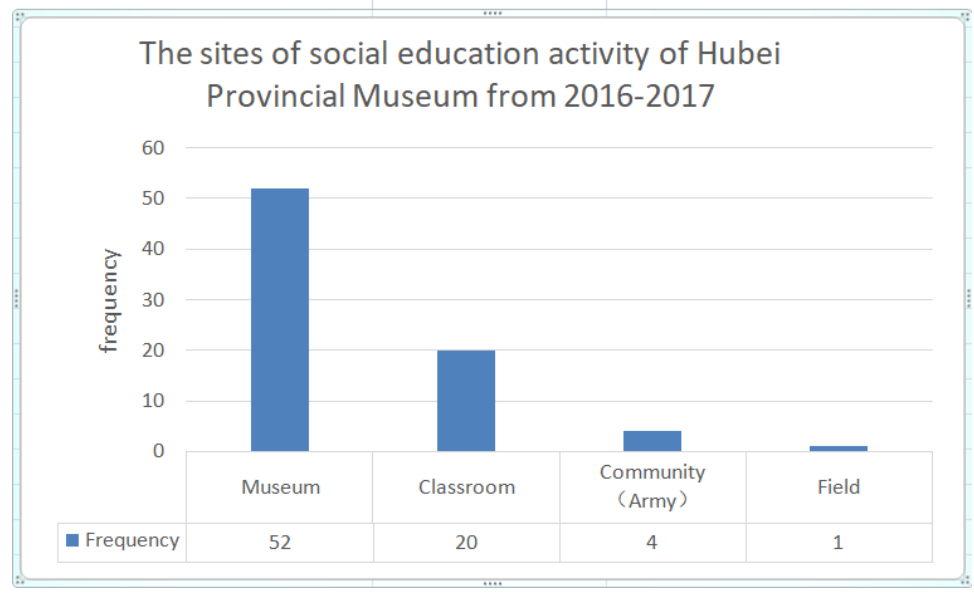

Figure 4. Sites of Social Education of Hubei Provincial Museum from 2016 to 2017

A question is still open for the researchers: What is the visitor's best place to take part in the social education of museums? What other places or forms can be chosen to improve the effect of 
social education?

\section{The Main Conclusions and Suggestions}

This study analyzed the educational activities of the Hubei Provincial Museum in 2011-2017, summed up the basic modes of social education activities, and proposed some questionable assumptions in social education of museums. To make social education more effective, this study gives suggestions for museum education as follows:

Chinese museums and scholars should make more study on the forms of education by specifying the contents and curriculum of museum education according to different teaching objects.

Museum educators should study the different teaching objects and learn to choose different teaching methods.

Museums should take full advantage of modern high-tech in making rich heritage resources great teaching resources. In the "Internet +" era, the construction of "Internet + Museum" and digital museums should be built on official website, by building a database of cultural relics and educational materials for tourists and learners, and researchers to create a permanent community for social education and long-life education.

\section{Acknowledgements}

This thesis is founded by the Key Project "Research on the Development and Utilization of Museum Cultural Resources in Higher Education" (DIA150312) of Ministry of Education of National Education Science 13th Five-year Plan Project.

\section{References}

[1] T.W. Sheng: Advancing with the Times and Expanding the Functions of Museum Education [J], Journal of Lanzhou University (Social Science Edition), 2010 (10), P115. (In Chinese).

[2] G. Ch. Zhang: Thinking of the Development of China's Museum Education [J], Journal of Jianghan University (Humanities Science Edition), 2012 (4), P34. (In Chinese).

[3] Ch. M. Zhao: On the Social Education of the Museum [J], Academia, 1987(6), P85. (In Chinese).

[4] B. W. Cao, Memory Scene and Culture Palace: Museum of Our Time [M], Beijing: Xueyuan Press, 2005. P21. (In Chinese).

[5] China Society of Museum Science and Education Committee, Proceedings of the Symposium on Scientific Outlook on Development and Museum Education [C], Xi'an: Shaanxi People's Publishing House, 2007. (In Chinese).

[6] Q. Yang \& Ch. M. Zhang: Connotation of Popular Science Education in Natural Museum [J], Journal of Shenyang Normal University (Social Science Edition), 2009(6), P142. (In Chinese).

[7] X. P. Fan: An Analysis of Educational Functions of Exhibitions and Exhibitions of Chinese Character Museum [J], Journal of Yindu, 2013(4), P120. (In Chinese).

[8] H. Jiang: Using Museum Resources to Improve Junior High School Art Education [J], Journal of Inner Mongolia Normal University, 2009(8), P33. (In Chinese).

[9] Y. Wang: The Discrimination of Museum Education in the Perspective of Modern Educational Theory [J], Journal of Inner Mongolia University for Nationalities, 2011(11), P62. (In Chinese).

[10]]Zheng Xudong, The Evolution from Museum Education to Gymnasium Learning: History and Logic [J], Modern Educational Technology, 2015(2):5. (In Chinese).

[11]Education Is the Core Function of Contemporary Museums, China Culture News[N], November 28, 2013. (In Chinese).

[12]Li Yuanhe, Function of Education and Entertainment in the Museum [J], Journal of Zhengzhou University: Philosophy and Social Sciences, 1992 (5): 100. (In Chinese).

[13]B. J. Chen, F.Yue \& F. J. Du: The Joy and Worry in the Development of the Museum [J], People's Forum, 2013 (9), P102. (In Chinese). 
[14]Y. Zheng: The Study on Museum Educational Activities[M], Shanghai: Fudan University Press, 2015, P39. (In Chinese).

[15]Anderson David \& J. Ji: From STEM Education to STEAM Education: A Conversation between David Anderson to Ji Jiao[J], Journal of East China Normal University, 2017 (4), P122. (In Chinese).

[16]H. Yu: Exploration and Practice: A Study of Museology [M], Beijing: China Social Sciences Press, 2017, P62. (In Chinese). 